\title{
Structural Model for Adoption and Usage of E-Banking in Vietnam
}

\author{
NGUYẼ̃N DUY THANH \\ HCMC University of Technology - thanh.nguyen@gmail.com \\ CAO HÀO THI \\ HCMC University of Technology - chthi@sim.hcmut.edu.vn
}

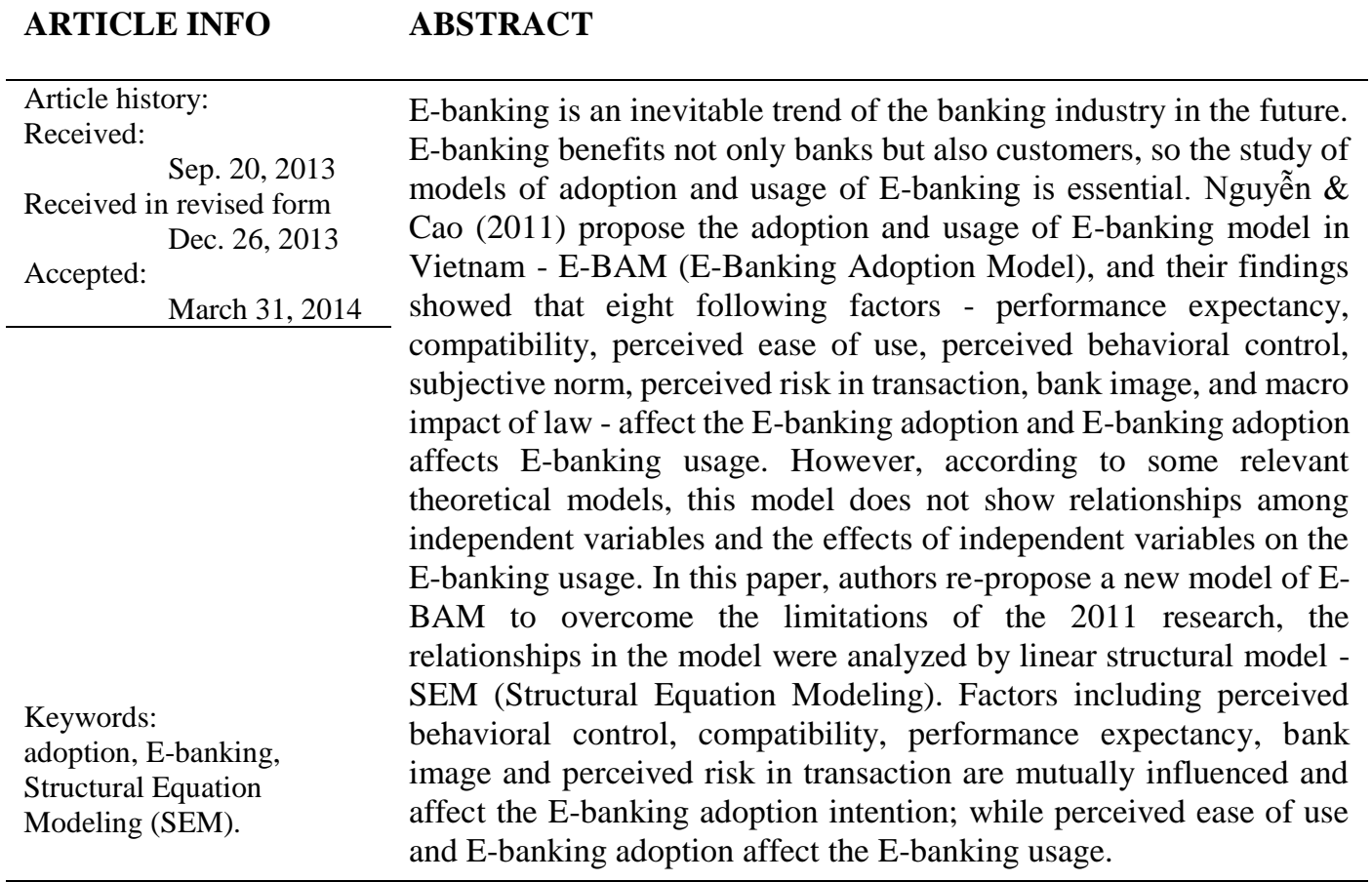




\section{INTRODUCTION}

\section{a. E-banking:}

Several main channels for E-banking studied by Daniel (1999); and Karjaluoto et al. (2003) are presented in Table 1. In addition, there are other channels for E-banking such as ATM (Auto Teller Machine), POS system (Point of Sale), digital wallet, and payment gateway, etc. As a new channel, E-banking is replacing other traditional banking channels for the benefits of both financial institutions and customers (Andreas, 2006).

Table 1: Some Main E-Banking Channels

\begin{tabular}{ll}
\hline \multicolumn{1}{c}{ Types } & \multicolumn{1}{c}{ Descriptions } \\
\hline PC Banking & $\begin{array}{l}\text { Proprietary software, distributed by the bank, is installed by the customer on } \\
\text { their PC. Access to bank via a modem linked directly to the bank. }\end{array}$ \\
$\begin{array}{l}\text { Managed } \\
\text { network }\end{array}$ & The bank makes online services provided by other parties. \\
Internet Banking & $\begin{array}{l}\text { Customers can access the banks via Internet (using their PC, web browsers). } \\
\text { TV Banking }\end{array}$ \\
Uhone Banking & $\begin{array}{l}\text { Customers access the banking account via their phones. } \\
\text { displayed on their TV screens. }\end{array}$ \\
Mobile Banking & $\begin{array}{l}\text { Customers access the banking account with text message (SMS), Internet } \\
\text { connection (WAP), high-speed connection provided by the } 3^{\text {rd }} \text { party. }\end{array}$ \\
\hline
\end{tabular}

\section{b. E-banking in Vietnam:}

According to reports by the National Internet Center, Vietnam was ranked $18^{\text {th }}$ among the world 20 top Internet countries, and compared to countries in Asia and Southeast Asia, the Vietnam's rank was respectively $8^{\text {th }}$ and $3^{\text {rd }}$ with about $36 \%$ of its population are Internet users (Ministry of Information and Telecommunication, 2013). The Vietnamese government plans to increase the ratio of Internet users to population to $55 \%$ - 60\% by 2020 (Vietnamese Government, 2012).

According to Cao et al. (2011), the growth rate of IT industry increased by $20 \%$ $25 \%$ on average in the past 10 years and is expected to rise to $30 \%$ by 2020 . However, per statistics gathered until Q3/2012 from Vietnam Banks Association, only 40 out of 62 local banks apply Internet banking and 18 banks offer mobile banking services. Other noteworthy figures are: roughly $20 \%$ of the Vietnamese populations are bank account holders, and E-banking accounts for only $15 \%$ of banking services they employ 
(Vietnam Banks Association, 2013). E-banking is considered a new and fastest-growing field in the world while it has just started to be used in Vietnam.

There are many researches on adoption of E-banking in the world but such researches in Vietnam, a potential market for banking services, are scarce. In their research on adoption and usage of E-banking model (E-BAM) in Vietnam, Nguyễn \& Cao (2011) propose a model integrating previous ones and the results show that the factors: performance expectancy, compatibility, perceived ease of use, perceived behavioral control, subjective norm, risk relating transaction, bank image and macro impact of law affect E-banking adoption that, in its turn, affects E-banking usage.

However, according to some relevant theoretical models, the model does not show relationships among independent variables and effects of independent variables on the E-banking usage. In this paper, authors re-propose a new model of E-BAM based on relevant theoretical model and findings by Nguyễn \& Cao (2011). The relationships in the model were analyzed by linear structural model - SEM (Structural Equation Modeling).

\section{THEORETICAL BASES AND RESEARCH MODEL}

\section{a. Theoretical Bases:}

According to Ajzen \& Fishbein $(1975 ; 1980)$, theory of reasoned action (TRA) is a research model based on the social psychology to identify factors of behavioral intention. Derived from TRA, Ajzen $(1985 ; 1991 ; 2002)$ proposes a theory of planned behavior (TPB) including perceived behavioral control. Based on the TRA, Davis et al. (1989; 1993) establish the technology acceptance model (TAM) to explain users' behaviors toward adoption and usage of information system.

Moreover, diffusion of innovations theory (IDT), developed by Rogers (1995), tries to explain user's adoption of technological innovations. Meanwhile, Venkatesh et al. (2003) describe a unified model, called unified theory of acceptance and use of technology (UTAUT) to explain behavioral intention and usage behavior toward information system.

Thus, the UTAUT is developed through eight models: the theory of reasoned action, the theory of planned behavior, the technology acceptance model, a model combining the theory of planned behavior and the technology acceptance model (Taylor \& Todd, 1995), the extension of diffusion of innovations theory (Moore \& Benbsat, 1991), the 
motivational model (Davis et al.., 1992), the model of PC utilization (Thompson et al.., 1991), and the social cognitive theory (Compeau and Higgins, 1995).

In the research by Nguyễn \& Cao (2011), E-BAM shows that the independent variables affect adoption of E-banking and adoption of E-banking affects usage of Ebanking, but the correlation between the independent variables and their impact on usage of E-banking are not indicated.

\section{b. E-banking Adoption Model:}

By examining actual conditions of E-banking in Vietnam and models TRA, TPB, TAM, TAM 2 (a theoretical extension of TAM, developed by Venkatesh \& Davis, 2000), IDT, UTAUT and relevant researches, authors repropose adoption and usage of E-banking model in Vietnam - E-BAM. The model can overcome the limitations concerning relationships among independent variables and their effects on E-banking usage. In the E-BAM model presented by Nguyễn \& Cao (2011), moreover, subjective norm has the least effect on E-banking adoption (EBA) with coefficient $\beta$ equaling only $0.087(\mathrm{p}=0.018)$. They also find that about $25 \%$ of surveyed people do not care about macro impact of law (MIL) because they think they could not do anything to macro factors, which implies that local users pay almost no attention to the legal aspect of Ebanking in particular and electronic transactions in general. Thus, subjective norm and macro impact of law are not included in this model.

Perceived ease of use (PEU) is defined as the degree to which customers believe that using E-banking system does not require much effort (Davis, 1989) (with five observed variables), referring to TAM by Davis et al.. (1991; 1993), TAM 2 by Venkatech \& Davis (2000), research on e-commerce adoption by Lee et al. (2001), researches on adoption and usage of Internet Banking by Podder (2005); Sattabusaya et al. (2007); Hernandez \& Mazzon (2007); Surapong (2009); Yaghoubi \& Bahmani (2010); Hosein (2010); Safeena et al. (2011); Nabil (2012); Abeka et al. (2012); Njuguna et al. (2012); and Ali et al.(2013), and researches on adoption and usage of E-banking by Bander (2008); Gibson \& Gibson (2009); Clegg et al. (2010); Sadeghi \& Farokhian (2011); Aliyu (2012); Mohammad (2012); Pham et al. (2013); Fonchamnyo et al. (2013).

Perceived behavioral control (PBC) is defined as customers' perception of E-banking system (with four observed variables) referring to the TBP model by Ajzen et al. (1986; $1991 ; 2002)$, the research on technology adoption by $\mathrm{Li}(2010)$, researches on adoption and usage of Internet Banking by Jaruwachirathanakul \& Fink (2005); Hernandez \& 
Mazzon (2007); and Majali \& Mat (2010), and researches on E-banking adoption by Yaghoubi \& Bahmani (2010); Sadeghi \& Farokhian (2011); Mohammad (2012); and Pham et al. (2013).

Compatibility (C) is the dissemination of changes in the E-banking technology in individual life and work (with six observed variables), referring to the IDT model by Rogers (1995), research on technology adoption by Li (2010), researches on adoption and usage of Internet banking by Podder (2005); Majali \& Mat (2011); Ali et al. (2013), and researches on adoption and usage of E-banking by Alagheband (2006); Gibson \& Gibson (2009); Mansumitrchai \& Malkawi (2011); and Abukhzam \& Lee (2012).

Performance expectancy (PE) is defined as the degree to which customers believe that E-banking system will help them to achieve better performance in bank-related jobs (with four observed variables) referring to the UTAUT model by Venkatesh et al. (2003), the research on technology adoption developed by $\mathrm{Li}$ (2010), and the research on adoption and usage of Internet banking by Kholoud (2009).

Bank image (BI) is defined as the effect of bank's typical images on customers' Ebanking adoption (with six observed variables) referring to the extension of IDT model by Moore \& Bembasat (1991), the research on consumer loyalty (Barbara \& Magdalini, 2006), the research on technology adoption by $\mathrm{Li}$ (2010), the research on adoption and usage of Internet banking by Hernandez \& Mazzon (2007), and the researches on Ebanking adoption by Sadeghi \& Farokhian (2011); and Pham et al. (2013).

Perceived risk in transaction (PRT) is defined as degree of risks of perceived by consumers when using an E-banking system (with four observed variables) referring to the E-CAM model by Lee et al. (2001), the research on perceived risk in online transaction by Li \& Huang (2009), researches on adoption and usage of Internet banking by Podder (2005); Sattabusaya et al. (2007); Narsi (2011); Mansumitrchai \& Malkawi (2011); Safeena et al. (2011); Nabil (2012); Njuguna et al. (2012); and Muzividzi et al. (2013), and researches on E-banking adoption by Alagheband (2006); Kurnia et al. (2009); Sadeghi \& Farokhian (2011); Shafei \& Mirani (2011); Aliyu (2012); Mohammad (2012); Abukhzam \& Lee (2012); and Pham et al. (2013).

E-banking adoption (EBA) is customers' adoption of E-banking (with the three observed variables), referring to the TAM by Davis et al. (1991; 1993), the TAM 2 by Venkatesh \& Davis (2000), the IDT model by Rogers (1995), researches on adoption and usage of Internet banking by Podder (2005); Sattabusaya et al. (2007); Hernandez 
\& Mazzon (2007); Surapong (2009); Wang \& Pho (2009); Yaghoubi \& Bahmani (2010); Hosein (2010); Majali \& Mat (2011); Njuguna et al. (2012); and Ali et al. (2013), and researches on E-banking adoption and usage by Jaruwachirathanakul \& Fink (2005); Bander (2008); Gibson \& Gibson (2009); Clegg et al. (2010); Shafei \& Mirani (2011); Mohammad (2012); Pham et al. (2013); and Fonchamnyo et al. (2013).

E-banking usage (EBU) is defined as the frequency by which customers use Ebanking products and services after adoption (with the two observed variables), referring to the TAM by Davis et al. (1991; 1993), the TAM 2 by Venkatesh \& Davis (2000), the UTAUT model by Venkatesh et al. (2003), researches on adoption and usage of Internet banking by Podder (2005); Sattabusaya et al. (2007); Hernandez \& Mazzon (2007); Bander (2008); Surapong (2009); Yaghoubi \& Bahmani (2010); Hosein (2010); Njuguna et al. (2012); and Ali et al. (2013), and researches on adoption and usage of E-banking by Clegg et al. (2010); Mohammad (2012); Fonchamnyo et al. (2013); and Pham et al. (2013).

The research establishes the following hypotheses:

- Relationships of the independent variables

$\mathrm{H} 1 \mathrm{a}^{+}$: Perceived ease of use has a positive reciprocal relationship to behavioral control.

$\mathrm{H}_{1} \mathrm{~b}^{+}$: Perceived behavioral control has a positive reciprocal relationship to compatibility.

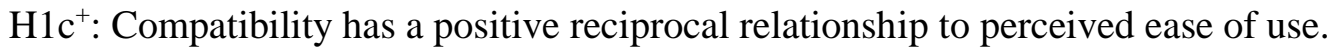

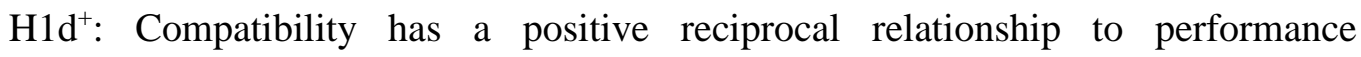
expectancy.

$\mathrm{H}_{1} \mathrm{e}^{+}$: Performance expectancy has a positive reciprocal relationship to bank image.

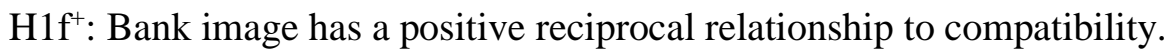

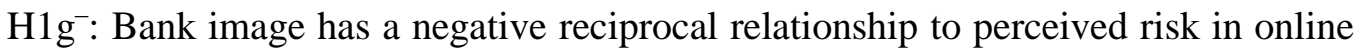
transaction.

- Effects on E-banking adoption (EBA)

$\mathrm{H}_{2} \mathrm{a}^{+}$: Perceived behavioral control has a positive impact on EBA.

$\mathrm{H}_{2} \mathrm{~b}^{+}$: Compatibility has a positive impact on EBA.

$\mathrm{H} 2 \mathrm{c}^{+}$: Performance expectancy has a positive impact on EBA. 
$\mathrm{H} 2 \mathrm{~d}^{+}$: Bank image has a positive impact on EBA.

$\mathrm{H} 2 \mathrm{e}^{-}$: Perceived risk in online transaction has a negative impact on EBA.

- Effects on E-banking usage (EBU)

$\mathrm{H}_{3} \mathrm{a}^{+}$: Perceived ease of use has a positive impact on EBU.

$\mathrm{H}_{3} \mathrm{~b}^{+}$: E-banking adoption has a positive impact on EBU.

\section{RESULTS AND DISCUSSION}

Observed variables are measured by the 7-point Likert scale and questionnaires are sent by post and email to surveyed people who have used or have intention to use Ebanking services in Vietnam. Gathered data are analyzed using SPSS and AMOS softwares. The preliminary research with a trial scale is conducted with 50 samples. Of 32 tentative variables, three are removed from the scale: $\mathrm{PBC}_{1}$ of perceived behavioral control, $\mathrm{C}_{1}$ of compatibility with Cronbach alpha $<0.06$ (as suggested by Nunnally, 1993), and $\mathrm{RPT}_{4}$ of perceived risk in transaction with factor loading in EFA < 0.50 (as suggested by Hair et al., 2006). Thus, the official research is conducted with 369 samples and 29 observed variables.

\section{a. Statistical Description of Samples:}

Gender: there is no significant difference between male $(51.50 \%)$ and female (48.50\%). Age: the 20-29 and 30-39 age groups represent $43.90 \%$ and $40.90 \%$ of respondents respectively; the remaining respondents are of other age groups. Education: higher education accounts for $53.70 \%$; postgraduate education $33.10 \%$; while respondents who have not finished secondary education represent $1.10 \%$. Job: office workers account for $37.10 \%$; lower manager $25.20 \%$; middle manager $16.50 \%$; and university and high school students $8.90 \%$. Income: VND5 - 9 million income bracket accounts for $38.80 \%$; 10 - 19.9 million bracket $27.10 \%$; and other brackets represent smaller proportions. Home region: $31.40 \%, 14.10 \%$ and $54.50 \%$ are proportions of surveyed people from the North, Central Vietnam and the South respectively. Bank account: accounts with joint-stock commercial banks represent 57.90\%; with stateowned ones $28.60 \%$; and foreign banks $10.90 \%$.

\section{b. Model and Hypotheses Testing:}

- Exploratory Factor Analysis (EFA):

From 27 observed variables, EFA extracts 7 factors that are divided into groups of components in rotated component matrix as required by the research model. The EFA 
results are presented in Table 2. The coefficient KMO is 0.896 at statistical significance of 0.000 implying that EFA of the independent components is appropriate. Total variance extracted of variables is $73.309 \%$, which implies that they can explain 73.309 $\%$ of variation in data.

With an extracted variance of $79.431 \%$, EBU can explain variation in data rather well. Factor loading of variables included in EBU is also high (>0.80).

Table 2: Structure of Components and Scale for E-BAM

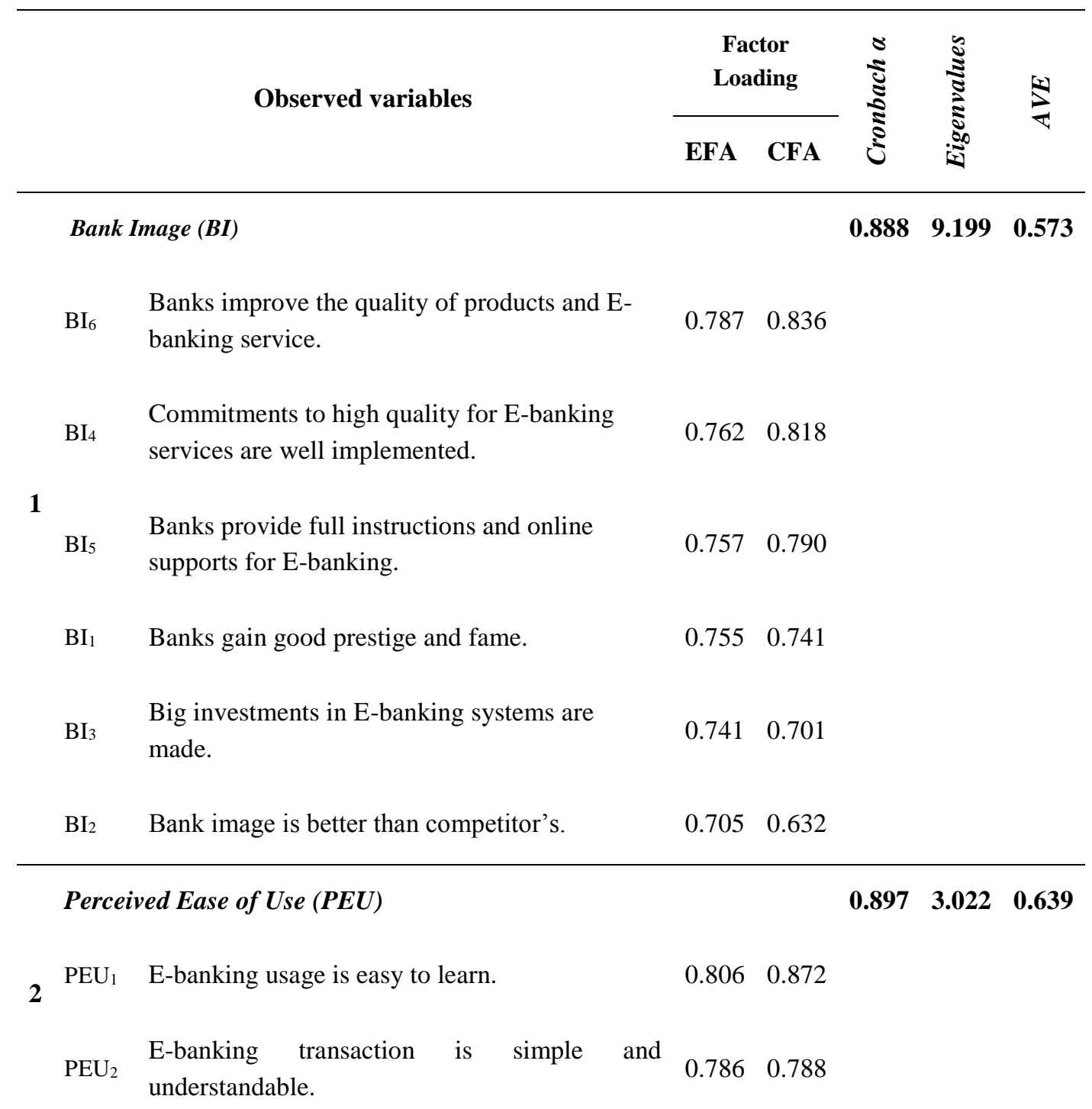


$\mathrm{PEU}_{4} \quad$ It is easy to use E-banking system skillfully. $\quad 0.766 \quad 0.797$

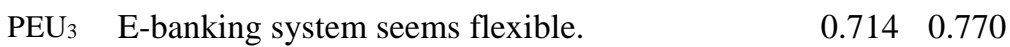

$\begin{array}{llll}\mathrm{PEU}_{5} \text { Using E-banking helps implement transactions at } & 0.706 \quad 0.768 \\ & \text { will }\end{array}$

Performance Expectancy (PE)

EE1 E-banking service seems to be useful and 0.7990 .877
convenient.

3

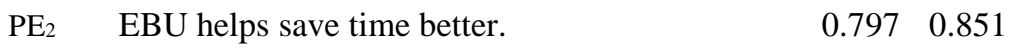

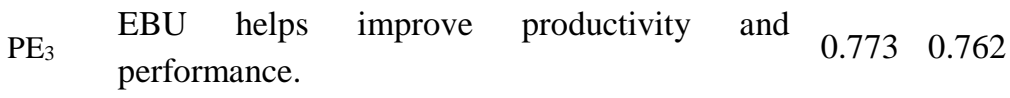

$\mathrm{PE}_{4} \quad$ E-banking helps complete bank-related activities quickly.

$0.764 \quad 0.737$

Perceived Behavioral Control (PBC)

$\begin{array}{lll}0.854 & 1.569 & 0.667\end{array}$

$\mathrm{PBC}_{3} \quad$ Necessary resources for EBU. $\quad 0.821 \quad 0.865$

4

$\mathrm{PBC}_{4} \quad$ Necessary knowledge for EBU. $\quad 0.803 \quad 0.789$

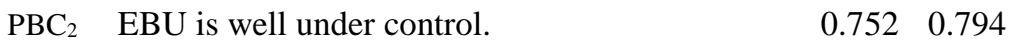

Perceived Risk in Transaction (PRT)

$\begin{array}{lll}0.835 & 1.146 & 0.637\end{array}$

$\mathrm{PRT}_{2}$ Confidentiality of transactions through E- 0.8860 .896 banking system is not secured.

5

$\begin{array}{llll}\mathrm{PRT}_{3} & \begin{array}{l}\text { Frauds and loss of money may happen when } \\ \text { using E-banking services. }\end{array} & 0.851 & 0.759\end{array}$

$\mathrm{PRT}_{1} \quad$ E-banking can fail to ensure privacy. $\quad 0.807 \quad 0.730$ 
Compatibility $(C)$

$\begin{array}{llll}0.807 & 1.034 & 0.591\end{array}$

$\mathrm{C}_{3} \quad$ Using E-banking is appropriate with the present
financial situation.

6

$\begin{array}{ll}\mathrm{C}_{2} & \text { Using E-banking is suitable for financial } \\ \text { management. }\end{array}$

$\begin{array}{llll}\mathrm{C}_{4} \quad \begin{array}{l}\text { Transaction through E-banking system is as easy } \\ \text { as transaction by cash. }\end{array} & 0.702 & 0.710\end{array}$

E-banking Adoption (EBA)

$\begin{array}{lll}0.864 & 1.723 & 0.632\end{array}$

EBA $_{3}$ E-banking is strongly recommended. $\quad 0.919 \quad 0.896$

7

$\mathrm{EBA}_{2} \quad$ E-banking can be used frequently in future. $\quad 0.881 \quad 0.747$

$\begin{array}{ll}\mathrm{EBA}_{1} & \text { I have inter } \\ \text { months. }\end{array}$

$\begin{array}{ll}0.866 & 0.731\end{array}$

Source: Results of analysis of Cronbach alpha, EFA and CFA.

- Confirmatory Factor Analysis:

Confirmatory Factor Analysis (CFA) demonstrates that the model is compatible with data. Table 3 shows that Chi-square $\left(\chi^{2}\right) / \mathrm{DF}=2.012$; $\mathrm{GFI}=0.890 ; \mathrm{TLI}=0.949 ; \mathrm{CFI}=$ 0.941; and RMSEA $=0.055$. Table 2 indicates that standardized CFA factor loadings of all observed variables are high, varying between 0.701 and 0.896 . According to Fornell \& Larcker (1981), the average variance extracted (AVE) varying from 0.573 to 0.667 (larger than 0.50) reflects a high convergent validity for the measures. In addition, the measures gain discriminant validity because all AVEs are larger than the corresponding squared correlation coefficients $\left(\mathrm{r}^{2}\right)$. Moreover, the Cronbach alpha values of all variables of components included in official measures are satisfactory, implying that they are good measures $(>0.80)$. The results of theoretical model test are shown in Table 3 with $\chi^{2} / \mathrm{DF}=1.806$; GFI $=0.905$; $\mathrm{TLI}=0.949$; $\mathrm{CFI}=0.956$; and $\mathrm{RMSEA}=0.047$, which shows that the model is compatible with the data. 
Table 3: CFA Indicator

\begin{tabular}{cccc}
\hline Indicator & $\begin{array}{c}\text { Reference } \\
\text { value }\end{array}$ & $\begin{array}{c}\text { Measurement } \\
\text { model }\end{array}$ & $\begin{array}{c}\text { Theoretical } \\
\text { model }\end{array}$ \\
\hline CMIN/DF $(\chi 2 / D F)$ & $\leq 2.00 *$ & 2.012 & 1.806 \\
GFI & $\geq 0.90 * *$ & 0.890 & 0.905 \\
TLI & $\geq 0.90 * *$ & 0.949 & 0.949 \\
CFI & $\geq 0.90 * *$ & 0.941 & 0.956 \\
RMSEA & $\leq 0.05 * * *$ & 0.052 & 0.047 \\
\hline
\end{tabular}

Source: ${ }^{*}$ Carmines \& McIver (1981), ${ }^{* *}$ Bentler \& Bonett (1980), ${ }^{* * *}$ Steiger (1990) and data of CFA in this research.

- SEM Analysis:

The results of SEM analysis presented in Table 4 show a correlation among PBC, PEU, and $C$, with $\beta=0.659$ (level of statistical significance of $p=0.000$ ) and $\beta=0.397$ $(\mathrm{p}=0.000)$ respectively, while PBC impacts on EBA with $\beta=0.475(\mathrm{p}=0.000)$, so H1a, $\mathrm{H} 1 \mathrm{~b}$ and $\mathrm{H} 2 \mathrm{a}$ are accepted.

$\mathrm{C}$ is correlated to PEU, PE and $\mathrm{BI}$ with respectively $\beta=0.554(\mathrm{p}=0.000), \beta=0.364$ $(p=0.000)$ and $\beta=0.224(p=0.000)$; and it also has an influence on EBA with $\beta=$ 0.364 ( $p=0.000)$, hence all four hypotheses H1c, H1d, H1f and H2b are accepted.

There exists a correlation between PE and BI with $\beta=0.565(p=0.000)$ and PE has an impact on EBA with $\beta=0.300(p=0.000)$, thus H1e and $\mathrm{H} 2 \mathrm{c}$ are accepted.

BI is negatively correlated to RPT with $\beta=-0.169(\mathrm{p}=0.002)$ and impacts on EBA with $\beta=0.347(p=0.000)$, which allows hypotheses H1g and H2d to be accepted.

PRT impacts negatively on EBA with $\beta=-0.138$ ( $p=0.033$ ), so H2e is accepted.

The impact of PEU on EBU has a coefficient $\beta$ equaling $0.599(p=0.003)$, therefore hypothesis $\mathrm{H} 3 \mathrm{a}$ is accepted.

EBA has an impact on EBU with $\beta=0.550(p=0.006)$, leading to acceptance of H3b.

In sum, test results show all hypotheses are accepted. Hypotheses H1a, H1b, H1c, $\mathrm{H} 1 \mathrm{~d}, \mathrm{H} 1 \mathrm{e}, \mathrm{H} 1 \mathrm{f}, \mathrm{H} 2 \mathrm{a}, \mathrm{H} 2 \mathrm{~b}$ and $\mathrm{H} 2 \mathrm{c}$ show that PEU, PBC, C, PE and BI have reciprocal relationships and impact positively on E-banking adoption; H1g and H2d imply that PRT 
has a reciprocal relationship to $\mathrm{BI}$ and impact negatively on EBA; while hypotheses $\mathrm{H} 3 \mathrm{a}$ and $\mathrm{H} 3 \mathrm{~b}$ show that PEU and EBA have a positive effect on E-banking usage.

Table 4: Relationships in E-BAM - SEM

\begin{tabular}{|c|c|c|c|c|c|c|c|c|c|}
\hline & $\begin{array}{c}\text { Hypothesis } \\
(\boldsymbol{H})\end{array}$ & & latio & nship & Estimate & $\begin{array}{l}\text { Standard } \\
\text { deviation }\end{array}$ & $\begin{array}{c}\text { Critical } \\
\text { value }(C R)\end{array}$ & $\begin{array}{c}\text { Significance } \\
(p \text {-value })\end{array}$ & Result \\
\hline 1 & $\mathrm{H} 1 \mathrm{a}^{+}$ & PEU & $\leftrightarrow$ & PBC & 0.659 & 0.071 & 8.388 & $* * *$ & Accepted \\
\hline 2 & $\mathrm{H} 1 \mathrm{~b}^{+}$ & PBC & $\leftrightarrow$ & $\mathrm{C}$ & 0.397 & 0.054 & 5.704 & $* * *$ & Accepted \\
\hline 3 & $\mathrm{H} 1 \mathrm{c}^{+}$ & $\mathrm{C}$ & $\leftrightarrow$ & PEU & 0.554 & 0.063 & 6.932 & $* * *$ & Accepted \\
\hline 4 & $\mathrm{H}_{1 d^{+}}$ & $\mathrm{C}$ & $\leftrightarrow$ & PE & 0.364 & 0.048 & 5.735 & $* * *$ & Accepted \\
\hline 5 & $\mathrm{H} 1 \mathrm{e}^{+}$ & PE & $\leftrightarrow$ & BI & 0.565 & 0.062 & 7.333 & $* * *$ & Accepted \\
\hline 6 & $\mathrm{H} 1 \mathrm{f}^{+}$ & BI & $\leftrightarrow$ & $\mathrm{C}$ & 0.244 & 0.041 & 4.206 & $* * *$ & Accepted \\
\hline 7 & $\mathrm{H} \mathrm{g}^{-}$ & BI & $\leftrightarrow$ & RPT & -0.169 & 0.039 & -3.175 & 0.002 & Accepted \\
\hline 8 & $\mathrm{H} 2 \mathrm{a}^{+}$ & PBC & $\rightarrow$ & EBA & 0.475 & 0.057 & 6.027 & $* * *$ & Accepted \\
\hline 9 & $\mathrm{H} 2 \mathrm{~b}^{+}$ & $\mathrm{C}$ & $\rightarrow$ & EBA & 0.364 & 0.072 & 4.166 & $* * *$ & Accepted \\
\hline 10 & $\mathrm{H} 2 \mathrm{c}^{+}$ & PE & $\rightarrow$ & EBA & 0.300 & 0.064 & 3.420 & $* * *$ & Accepted \\
\hline 11 & $\mathrm{H} 2 \mathrm{~d}^{+}$ & BI & $\rightarrow$ & EBA & 0.347 & 0.066 & 4.085 & $* * *$ & Accepted \\
\hline 12 & $\mathrm{H} 2 \mathrm{e}^{-}$ & RPT & $\rightarrow$ & EBA & -0.138 & 0.051 & -2.129 & 0.033 & Accepted \\
\hline 13 & $\mathrm{H} 3 \mathrm{a}^{+}$ & PEU & $\rightarrow$ & EBU & 0.599 & 0.075 & 2.936 & 0.003 & Accepted \\
\hline 14 & $\mathrm{H} 3 b^{+}$ & EBA & $\rightarrow$ & EBU & 0.550 & 0.105 & 2.730 & 0.006 & Accepted \\
\hline
\end{tabular}

$* * * \mathrm{p}<0,001$

Source: Results of SEM analysis.

\section{c. Discussion:}

There are several relevant researches in Vietnam: Trương \& Lê (2008) apply the model of technological adoption to E-banking adoption based only on TAM, while Pham al et. (2013) propose a model of E-Banking adoption in Vietnam without offering 
specific research results. In this research, authors develop the E-BAM by integrating different theoretical models such as TRA, TPB, TAM, TAM 2, IDT and UTAUT, and the research results are based on analyses of samples gathered nationwide.

The results of SEM analysis in E-BAM as presented in Figure 1 show that factors PEU (perceived ease of use), PBC (perceived behavioral control), C (compatibility), PE (performance expectancy), and BI (bank image) are correlated with at least two other factors. Specifically, the strongest inverse correlation is found between PEU and PBC with $\beta$ equaling $0.659(\mathrm{p}=0.000)$; while PRT has the weakest inverse correlation to BI with $\beta$ equaling $-0.169(\mathrm{p}=0.002)$.

Moreover, PBC, C, PE, BI and PRT have impacts on E-banking adoption, and the strongest impact is from $\mathrm{PBC}$ with $\beta=0.475(\mathrm{p}=0.000)$ and the weakest one is from PRT with $\beta=-0.138(p=0.033)$. Due to a negative regression coefficient $\beta$ of PRT ( $\beta$ $<0$ ), there exists an impact in which the higher the level of risk, the lower the level of E-Banking adoption, and vice versa.

PEU has a direct impact on E-banking usage with coefficient $\beta=0.599(p=0.003)$, showing that people will be ready to use E-banking service when it is easy. Additionally, there is a correlation between EBA and EBU with a coefficient $\beta$ of $0.550(p=0.006)$, which implies that the higher the adoption of E-banking, the broader the usage of Ebanking.

Generally, the research results reflect correlations between independent components, and confirm that EBU is directly affected by EBA and PEU. 


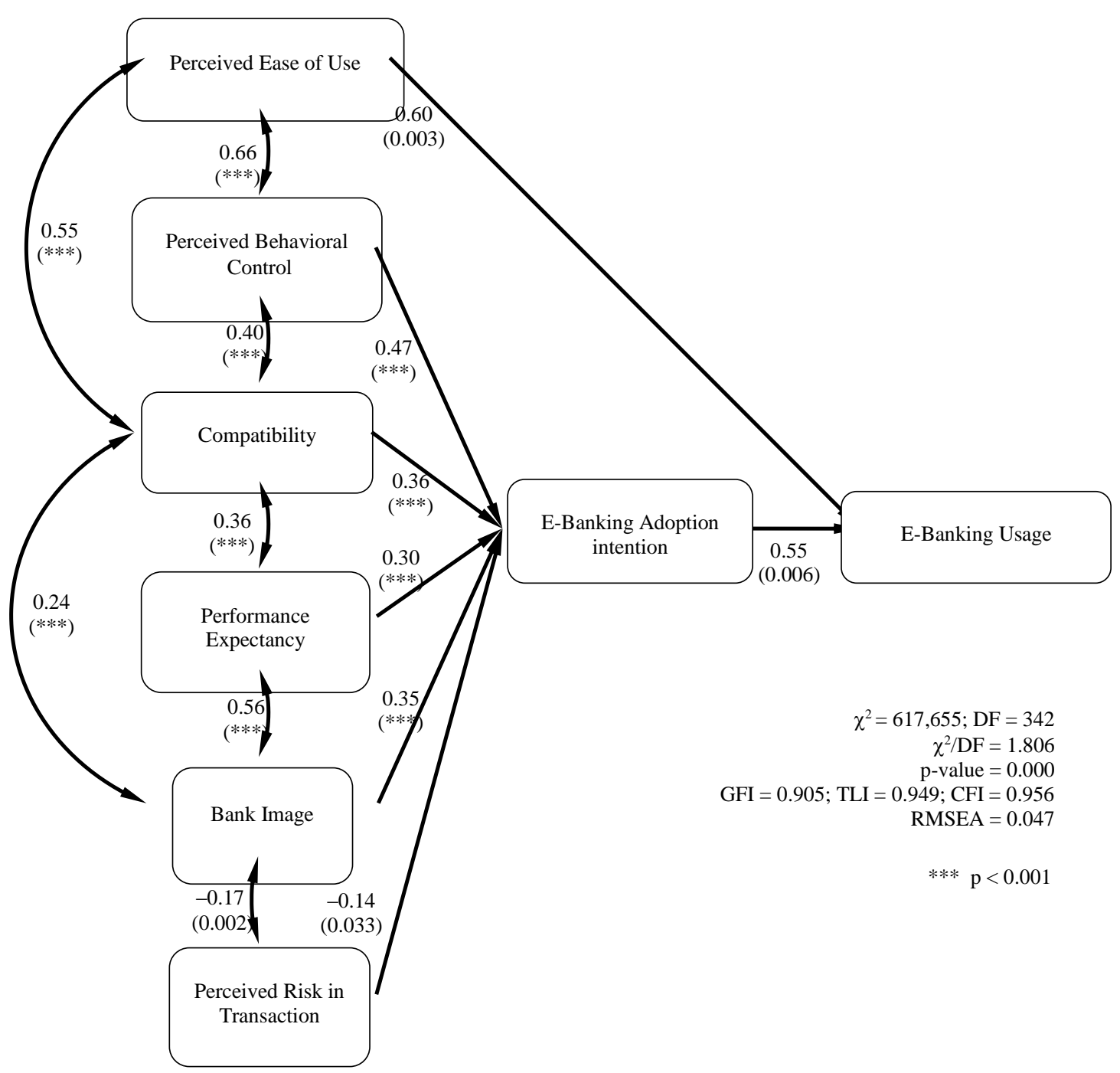

Figure 1: Model of E-Banking Adoption and SEM

Source: Proposed research model and research results

\section{RESULTS AND RECOMMENDATIONS}

\section{a. Results:}

The results from E-BAM show that measures for variables (adoption and usage of Ebanking) ensure the reliability. Both EFA and CFA for the variables produce high factor loadings, and their measures obtain the discriminant validity. Moreover, the SEM 
analysis shows the factors as perceived behavioral control, compatibility, performance expectancy, bank image and transaction-related risk have mutual influence and affect the E-banking adoption; meanwhile, both perceived ease of use and adoption of Ebanking have an impact on E-banking usage.

All of 14 hypotheses proposed by the research model are accepted. Moreover, the EBAM indicates the correlations between the independent factors and the impact of PEU on EBU which is not demonstrated in the previous study by Nguyễn \& Cao (2011). Adoption and usage of E-banking in Vietnam is well explained by high model testing weights.

\section{b. Recommendations:}

E-BAM identifies the factors that impact on adoption and usage of E-banking in Vietnam, thereby evaluating different impacts of these factors on EBU and EBA. The research results can serve as a basis for relevant studies in Vietnam. However, the results still have several limitations. Future researches need to acquire a larger sample and extend the scope of the study, adjust the measures according to development of Ebanking service in Vietnam and the world, include demographic factors in the SEM, and add several measures for such factors as service quality and socio- cultural effects.

The research results are also basis for Vietnam's banks to strengthen adoption and usage of E-banking services. The research shows that perceived ease of use has the strongest effect on E-banking usage. Although this factor depends much on technology and personal competence, banks should design so comprehensive E-banking products that customers can easily understand and use them. Interfaces of E-banking services should be customer friendly and flexible enough to help customers get access to other banking services. Additionally, risk involved in online transactions is a reason for customers' hesitation in adoption and usage of E-banking, because there exist information crimes worldwide and "criminal activity may even initiated by using the consumer's personal information to create false identities" (Ratnasingham, 1998).

In Vietnam, about 20 electronic banks have serious security gaps that can make hackers easily attack customers' computers, steal personal information, insert malicious codes into banking host server and control total E-banking system. These gaps are caused by banks' failure to pay attention to information security, establish a process of independent evaluation of internet security and invest in system security (Bkis, 2010). 
To reduce risk involved in online transactions, banks should build an effective system of information security for customers when they make transactions through E-banking system. The influence of PEU on E-Banking adoption and usage is enhanced by helping customer save their time and expenditures on transactions through banks. There should be a cooperation between banks in applying uniformly new technologies, expanding electronic networks such as Banknet, Smartlink, Inter Banking Payment System (IBPS), and Host2Host, etc., improving efficiency of new technological applications and shortening the time for handling transactions through E-banking channels.

The banks can also promote E-banking adoption and usage by enhancing E-banking service quality, building up customer's loyalty and domino effect of E-banking usage. Last but not least, banks should introduce measures to raise frequency of usage of Ebanking products and services and encourage customers to transfer to E-banking channels

\section{References}

Abeka, S., E. Abeka \& O. Omondi (2012), "Determinants of Adoption of Internet Banking by Trade Finance customers in East Africa”, International Journal of Academic Research in Accounting Finance and Management Sciences, 2 (2) 110-120.

Abukhzam, M. \& A. Lee (2012), "Factors Affecting Bank Staff Attitude towards E-Banking Adoption in Libya", The Electronic Journal of Information Systems in Developing Countries, 42 (2) 1-15.

Ajzen, I. \& M. Fishbein (1980), Understanding Attitudes and Predicting Social Behavior, Englewood Cliffs, NJ: Prentice Hall.

Ajzen, I. (1985), "From Intentions to Actions: A Theory of Planned Behavior" in J. Kuhl \& J. Beckman (Eds.), Action-Control: From Cognition to Behavior (pp. 11- 39), Heidelberg, Germany: Springer.

Ajzen, I. (2002), "Perceived Behavioral Control, Self-Efficacy, Locus of Control, and the Theory of Planned Behavior”, Journal of Applied Social Psychology, 32, 665-683.

Ajzen, I. (1991), “The Theory of Planned Behavior", Organizational Behavior and Human Decision Processes, 50, 179-211.

Alagheband, P. (2006), “Adoption of Electronic Banking Services by Iranian Customers”, Master thesis, Iran.

Ali, A. \& N. Khalil (2013), "Evaluation of Internet Banking Service Adoption among Yemen Customers", Kuwait Chapter of Arabian Journal of Business and Management Review, 2 (6) 3948. 
Aliyu, A., S. Younus \& R. Tasmin (2012), “An Exploratory Study on the Adoption of Electronic Banking: Underlying Consumer Behavior and Critical Success Factors: Case of Nigeria", Business and Management Review, 2 (1) 1-6.

Bander, A. (2008), "Internet Banking Acceptance Model Across Cultures: The Case of England and Saudi Arabia", PhD symposium, Brunel University.

Barbara, S. \& S. Magdalini (2006), "The Antecedents of Consumer Loyalty in Retail Banking”, Journal of Consumer Behavior, 5 15-31.

Bellman, S., G. Lohse \& E. Johnson (1999), "Predictors of Online Buying Behavior", Communications of the ACM, 42 (4) 32-38.

Bentler, M. \& G. Bonett (1980), "Significance Tests and Goodness-of-Fit in the Analysis of Covariance Structures", Psychological Bulletin, 88 588-600.

Bkis (2010), “100\% hệ thống ngân hàng điện tử hổng bảo mật", retrieve from http://ictnews.vn/home/Bao-mat/19/Bkis-100-ngan-hang-dien-tu-hong-bao-mat/26629/index.ict, on April 15, 2010.

Carmines, G. \& P. McIver (1981), "Analyzing Models with Unobserved Variables: Analysis of Covariance Structures" in Bohrnstedt, G.W. \& Edgar F. Borgatta (eds.), Social Measurement: Current Issues. Beverly Hills, CA: Sage Publications, 65-115.

Cao Hào Thi et al. (2011), "Dự báo nhân lực công nghệ thông tin TP. HCM đến năm 2020”, Phát triển khoa học và công nghệ, 14 (2) 14-21.

Clegg, B., S. Abdullah \& R. Gholami (2008), "Internet Banking Acceptance in the Context of Developing Countries: An Extension of the Technology Acceptance Model”, Operations \& Information Management Group, Aston Business School, UK.

Compeau, Z. \& C. Higgins (1995), “Application of Social Cognitive Theory to Training for Computer Skills”, Information Systems Research, 6 (2) 118-143.

Daniel, E. (1999), "Provision of E-Banking in the UK and Republic of Ireland”, International Journal Of Bank Marketing, 17 (2) 72-82.

Davis, F. D. (1989), "Perceived Usefulness, Perceived Ease of Use, and User Acceptance of Information Technology”, MIS Quarterly, 13 (3) 319-340.

Davis, F. D. (1993), "User Acceptance of Information Technology: System Characteristics, User Perceptions and Behavioral Impacts", International Journal of Man-Machine, 38, 475-487.

Davis, F., R. Bagozzi \& P. Warshaw (1992), "Extrinsic and Intrinsic Motivation to Use Computers in the Workplace”, Journal of Applied Social Psychology, 22 (14) 1111-1132.

Fishbein, M. \& I. Ajzen (1975), Belief, Attitude, Intention and Behavior: An Introduction to Theory and Research, Addison-Wesley Publishing Company. 
Fonchamnyo, C. D. (2013), “Customers' Perception of E-banking Adoption in Cameroon: An Empirical Assessment of an Extended TAM”, International Journal of Economics And Finance, 5 (1) 166-176.

Fornell, C. \& D. F. Larcker (1981), "Evaluating Structural Equation Models with Unobservable Variables and Measurement Error”, Journal of Marketing Research, 18 (1) 39-50.

Gibson, L.G. \& R.A. Gibson (2009), "Chinese American Internet Banking Acceptance: Implications for Multicultural Marketing”, in 2009 ICSB World Conference, International Council for Small Business (June 21-24, 2009, Seoul, Korea), The Dynamism of Small Business: Theory, Practice, and Policy, p. 97.

Hair, J., W. Black, B. Babin, R. Anderson \& R. Tatham (2006), Multivariate Data Analysis, $6^{\text {th }}$ edition, NJ: Prentice Hall.

Hernandez, C. \& A. Mazzon (2007), “Adoption of Internet Banking: Proposition and Implementation Integrated Methodology Approach”, International Journal of Bank Marketing, 25 (2) 72-88.

Hosein, Z. N. (2010), "Internet Banking Understanding Consumer Adoption Rates Among Community Banks", Journal of Business and Economic Research, 7 (11) 51-72.

Jaruwachirathanakul, B. \& D. Fink (2005), "Internet Banking Adoption Strategies for a Developing Country: The Case of Thailand", Internet Research, 15, 295-311.

Karjaluoto, Z., M. Mattila \& T. Pento (2003), "Electronic Banking in Finland, Consumer Beliefs and Reactions to New Delivery Channel”, Journal of Financial Services Marketing, 6 (4), 261-272.

Kholoud, I.A. (2009), “Analyzing the Use of UTAUT Model in Explaining an Online Behavior: Internet Banking Adoption", doctoral dissertation, Brunel University.

Kurnia, S., F. Peng \& Y. Liu (2010), "Understanding the Adoption of Electronic Banking in China", in Proceedings of the 43rd Hawaii International Conference on System Sciences.

Lee, D., Park J. \& J. H. An (2001), “On the explanation of factors affecting E-Commerce adoption”, in proceedings of the $22^{\text {nd }}$ International Conference on Information Systems, Korea.

Li, Y. \& J. Huang (2009), “Applying Theory of Perceived Risk and Technology Acceptance Model in the Online Shopping Channel”, International Journal of Business, Economics, Finance \& Management; 2 (2), 132.

Li, L. (2010) “A Critical Review of Technology Acceptance Literature”, research paper, Management Information Systems, Grambling State University.

Majali, M. \& M. Nat (2010), “Applications of Planned Behavior Theory on Internet Banking Services", China-USA Business Review, 9 (12).

Mansumitrchai, S. \& Husam-Aldin N. AL-Malkawi (2011), "Factors Underlying the Adoption of Online Banking by Mexican Consumers", International Journal of Business and Management, 6 (9) $155-169$. 
Ministry of Information and Communication (2013), “Tình hình sử dụng Internet ở Việt Nam, Tổng kết 15 năm hoạt động của Internet Việt Nam.” a report.

Mohammad, O. A. (2012), "Factors Affecting Adoption of Electronic Banking: An Analysis of the Perspectives of Banks' Customers", International Journal of Business and Social Science, 3 (17) 294-309.

Moore, G. \& I. Benbasat (1991), "Development of Instrument to Measure the Perceptions of Adopting Information Technology Innovation”, Information Systems Research, 2 (3) 192-222.

Muzividzi, D., R. Mbizi \& T. Mukwazhe (2013), “An Analysis of Factors that Influence Internet Banking Adoption Among Intellectuals Case of Chinhoyi University of Technology", Interdisciplinary Journal Of Contemporary Research in Business, 4 (11) 350-369.

Nabil, H. A. (2012), 'Factors Affecting the Adoption of Internet Banking amongst IIUM' Students: A Structural Equation Modeling approach”, Journal of Internet Banking and Commerce, 17 (3).

Nguyễn Duy Thanh \& Cao Hào Thi (2011), "Đề xuất mô hình chấp nhận và sử dụng ngân hàng điện tử ở Việt Nam”, Phát triển khoa học và công nghệ, 14 (2) 97-105.

Njuguna, K. P., C. Ritho, T. Olweny \& M. P. Wanderi (2012), "Internet Banking Adoption in Kenya: The Case of Nairobi County", International Journal of Business and Social Science, 3 (18) 246252.

Nunnally, J. \& I. Bernstein (1994), Psychometric Theory, McGraw Hill, New York.

Papandreou, A. (2006), “Internet Banking in Greece: Development, Evaluation and Perspectives”, Blekinge Institute of Technology, Sweden.

Pedhazur, E. J. (1997), Multiple Regression in Behavioral Research, $3^{\text {rd }}$ edition, Orlando, FL: Harcourt Brace.

Phạm Long, Cao Y. Nhi, Nguyễn D. Thanh \& Trần T. Phong (2013), "Structural Models for EBanking Adoption in Vietnam”, International Journal of Enterprise Information System, 9 (1) 3148.

Podder, B. (2005), "Factors Influencing the Adoption and Usage of Internet Banking: A New Zealand Perspective", doctoral dissertation, New Zealand.

Ratnasingham, P. (1998), “The Importance of Trust in Electronic Commerce”, Internet Research, 8 (4) 313-321.

Riyadh, A. \& M. Akter (2009), “The Adoption of E-Banking in Developing Countries: A Theoretical Model for SMEs”, International Review of Business Research Papers, 5 (2) 212-230.

Rogers, E. (1995), Diffusion of innovations, Free Press, New York.

Sadeghi, T. \& S. Farokhian (2011), "The Role of Behavioral Adoption Theories in Online Banking Services”, Middle-East Journal of Scientific Research, 7 (3) 374-380.

Safeena, R., H. Date \& A. Kammani (2011), "Internet Banking Adoption in an Emerging Economy: Indian Consumer's Perspective”, International Arab Journal of E-Technology, 2 (1) 57-64. 
Sattabusaya, D., J. Pallister \& G. Foxall (2007), "Keys Factors that Determine Internet Banking Adoption in Thailand", 16th Edamba summer academy, Soreze, France.

Shafei, R. \& V. Mirani (2011), "Designing a Model for Analyzing the Effect of Risks on E-Banking Adoption by Customers: A Focus on Developing Countries", African Journal of Business Management, 5 (16) 6684-6697.

Steiger, H. (1990), "Structural Model Evaluation and Modification", Multivariate Behavioral Research, 25 214-12.

Surapong, P. (2009), “Adoption and Use of Personal Internet Banking Services in Thailand", The Electronic Journal of Information Systems in Developing Countries, 37 (6) 1-31.

Taylor, S. \& P. Todd (1995), "Understanding Information Technology Usage: A test of Competing Models", Information System Research, 6 (2) 144-176.

Thompson, R., C. Higgins \& J. Howell (1991), "Personal Computing: Toward a Conceptual Model of Utilization”, MIS Quarterly, 15 (1) 125-143.

Trương Thị Vân Anh \& Lê Văn Huy (2008), "Ứng dụng mô hình TAM trong nghiên cứu E-Banking ở Việt Nam”, in proceedings of a scientific research conference, Đà Nẵng University.

Venkatesh, V. \& F. Davis (2000), “A Theoretical Extension of the Technology Acceptance Model: Four Longitudinal Field Studies”, Management Science, 46 (2) 186-204.

Venkatesh, V., M. Morris \& F. Davis (2003), “User Acceptance of Information Technology: Toward a Unified View”, MIS Quarterly: Management Information Systems, 27 425-478.

Vietnam Banks Association (2013), “Thúc đẩy dịch vụ ngân hàng đa kênh hiệu quả”, in proceedings of a conference on E-Banking.

Vietnamese Government (2012), "Phê duyệt Quy hoạch phát triển viễn thông quốc gia đến năm 2020", and "Decision 32/2012/QĐ-TTg".

Wang, J.S. \& Pho Thien-Son (2009), "Drivers of Customer Intention to Use Online Banking: An Empirical Study in Vietnam”, African Journal of Business Management, 3 (11) 669-677.

Yaghoubi, N. \& E. Bahmani (2010), "Factors Affecting the Adoption of Online Banking: An Integration of Technology Acceptance Model and Theory of Planned Behavior", International Journal of Business and Management, 5 (2) 159-165. 